\title{
Level of physical activity and perceived barriers to its practice in adults with visual impairment
}

\author{
Nível de atividade física e barreiras percebidas para sua prática em adultos com \\ deficiência visual
}

AUTHOR'S
$\begin{aligned} & \text { Gabriely Portela Matoso }{ }^{1} \text { (D } \\ & \text { Bruno Sergio Portela }{ }^{1} \text { (D) }\end{aligned}$
1 Universidade Estadual do Centro-Oeste.
Guarapuava, Paraná, Brazil.
CORRESPONDING
Bruno Sergio Portela
bruno_sergio_por@yahoo.com.br
Rua Alameda Élio Antonio Dalla Vecchia,
838, Vila Carli, Guarapuava, Paraná, Brazil.
CEP: 85040-167.
DOI

$10.12820 /$ rbafs.24e0094

\begin{abstract}
The objective of the study was to assess level of physical activity, perception of barriers to practice, and stages of behavior change in visually impaired individuals of an inland city in the State of Paraná. The participants were 40 individuals with visual impairment ( $37.5 \%$ blind and $62.5 \%$ with low vision) of both sexes (57.5\% men) aged 21-69 years (mean age 39.52 years; \pm 17.58 for men and 39.88 years; \pm 14.96 for women). Participants were assessed in only one moment, through three questionnaires (perception of barriers to physical activity, International Questionnaire of Physical Activity (IPAQ) short version, and stages of behavior change). According to the IPAQ results, a prevalence of $70 \%$ of physical inactivity was found. The main barriers mentioned by the interviewees were "lack of support from family and/or friends", "physical limitations" and "bad mood". In relation to the questionnaire of stages of behavior change, $50 \%$ of the subjects were in the preparation stage. The study concludes that the level of physical activity in the visually impaired is low and the main causes of this can be motivational, lack of physical fitness and psychological.
\end{abstract}

Keywords: Physical activity; Vision disorders; Behavior.

RESUMO

O objetivo do estudo foi avaliar o nivel de atividade física, a percepção de barreiras para a prática e os estágios de mudança de comportamento em deficientes visuais de um município do interior do Paraná. Participaram deste estudo 40 individuos com deficiência visual (37,5\% cegos e 62,5\% com baixa visão), de ambos os sexos (57, 5\% homens) com idade entre 21 e 69 anos (média de 39,52 anos; \pm 17,58 para os homens e 39,88; $\pm 14,96$ para as mulheres). Os participantes foram avaliados em apenas um momento, por meio de três questionários (percepşão de barreiras para atividade física, Questionário Internacional de Atividade Física (IPAQ) versão curta e estágios de mudança de comportamento). Conforme os resultados do IPAQ, mostra-se uma prevalência de 70\% de inatividade física. As barreiras que mais se destacaram nos entrevistados foram "falta de incentivo da família elou amigos", "limitaçôes físicas" e "mau humor". Em relação ao questionário de estágios de mudança de comportamento, 50\% dos avaliados estão no estágio de preparação. O estudo conclui que o nivel de atividade física em deficientes visuais é baixo e as principais causas podem ser motivacionais, falta de aptidão e psicológicas.

Palavras-chave: Atividade física; Transtornos da visão; Comportamento.

\section{Introduction}

The practice of physical activity results in countless benefits to health, both physical and mental ${ }^{1}$. Studies have shown that these benefits reduce mortality rates, decrease the risk of developing coronary heart disease and diabetes, and lower body adiposity levels ${ }^{2}$. Low levels of physical activity increase the risk of developing pathologies related to hypertension, obesity and cancer, negatively affecting the health of individuals ${ }^{1}$.

According to Malta et al., compared to other impairments, visual impairment presents a high prevalence index in the Brazilian population: $3.6 \%$ or approximately 7.2 million people with this incapacity in
$2013^{3}$. In addition, the south region of Brazil presents a higher percentage when compared to the other Brazilian regions: $5.9 \%$.

Physical activity levels are significantly low in visually impaired individuals when compared to non-impaired subjects, which can make them more susceptible to developing health problems related to an inactive life $\mathrm{e}^{4}$. Due to the scarcity of studies assessing the physical activity level of visually impaired individuals, it is necessary to understand how they behave in relation to the intention of starting their practice or maintaining it. It has been found that the daily level of physical activity of children and adolescents with visual impair- 
ment is lower than that of their non-impaired peers: while the visually impaired present an average of daily periods of moderate to vigorous physical activity of 7.31 ( \pm 2.26$)$, this figure, to the non-impaired, amounts to $12.20( \pm 4.24)^{5}$. Thus, it is important to assess the behavior of the visually impaired in relation to physical activity, aiming to understand if the impairment interferes in their decision-making process regarding the practice of physical activity.

Besides preventing the pathologies mentioned above, physical activity in the population of visually impaired individuals increases their quality of life and brings many physical benefits, such as improvement in physical fitness, coordination, balance, muscle strength, agility and speed, as well as psychological benefits, such as improvement in self-image and concept, self-confidence and motivation ${ }^{6}$. Among the different benefits of physical activity for this population, we highlight health promotion, independence and autonomy ${ }^{7}$.

However, the blind person's accessibility to physical activity is more limited when compared to the non-impaired population due to several factors that can be considered barriers. Some barriers to the practice of physical activity by visually impaired individuals have been portrayed by previous studies, like architectural difficulties, unprepared Physical Education teachers, overprotective families, and lack of spatial ability and motor coordination, as well as fear, dependence and motor delays as characteristics of people with visual impairment ${ }^{8}$.

Studies with different populations have been developed with the aim of identifying the barriers that hinder the regular practice of physical activity ${ }^{9}$. However, few studies in Brazil have analyzed this theme in the visually impaired population. Up to now, only the study carried out by Morgado et al. ${ }^{8}$ has analyzed qualitatively the barriers to physical activity in Brazilian visually impaired individuals.

The identification and classification of possible barriers to the practice of physical activity by the visually impaired are necessary for the creation and development of individualized intervention programs and methods that efficiently increase the level of physical activity in this population. In view of this need, the objective of this study was to assess level of physical activity, perception of barriers to practice and stages of behavior change of visually impaired individuals.

\section{Methods}

The present research is a cross-sectional study. The par- ticipants were 40 visually impaired adults attending APADEVI, the Association of Parents and Friends of the Visually Impaired of Guarapuava, State of Paraná. The association is a not-for-profit, non-governmental organization that assists people with complete visual impairment or low vision. It provides pedagogical activities and activities for the inclusion of the visually impaired in society. In this study, all the visually impaired individuals enrolled in the institution were assessed; therefore, sample size calculation was not performed, as we believe the association assists almost the total number of visually impaired individuals of the city (it monitors and assists all the city's visual impairment cases).

The study was submitted to the appraisal of the Ethics Committee for Research Involving Human Beings of Universidade Estadual do Centro-Oeste (UNICENTRO) and was approved under the opinion no. 2.347.960. As the institution is related to a state school, the study was also evaluated and approved by the Department of Education of the State of Paraná (SEED). After the approval of the Ethics Committee, the subjects were requested to sign the consent document known as TCLE, authorizing their participation in the research. Due to the visual impairment, the researcher read the document to the subject.

The research team was composed of two Physical Education students and the supervising teacher. Data collection occurred within a period of 3 months, in which the researchers went to the institution twice a week to administer the questionnaires. The questionnaires were administered through an interview with the visually impaired individual.

To assess the level of physical activity, the International Questionnaire of Physical Activity (IPAQ) - short version ${ }^{11}$ was used. It classifies the assessed subjects as very active or active (individuals who comply with the recommendations of $\geq 150$ minutes per week) and physically inactive (individuals who do not comply with the recommendations of frequency or duration of physical activity) ${ }^{12}$.

The questionnaire of perception of barriers was used to identify situations perceived by the visually impaired as obstacles to the practice of physical activity ${ }^{13}$. This questionnaire contains a list with 19 barriers that hinder the individual's decision-making process regarding the regular practice of physical activity: extensive working hours, family commitments (parents, spouse, child, etc.), inadequate weather (wind, cold, heat, etc.), lack of an available space to the practice, lack of equip- 
ment, domestic chores, lack of company, lack of support from family and/or friends, lack of financial resources, bad mood, fear of being injured, physical limitations (for example, muscle or joint limitations), mild pain or discomfort, lack of energy (physical tiredness), lack of physical skills, lack of knowledge or guidance about physical activity, insufficiently safe environment (criminality), concern about one's appearance during practice, and lack of interest in practicing. The subject classified each barrier in a factor measured as "always", "almost always", "sometimes", "almost never" or "never".

To assess the associations between stages of behavior change, levels of physical activity and barriers to practice, we decided to group the stages in the following way: a) maintenance and action, encompassing individuals considered physically active; b) preparation, contemplation and pre-contemplation, encompassing individuals considered inactive or irregularly active. This stratification of the stages of behavior change is consistent with analyses performed in previous studies ${ }^{14}$.

Data analysis encompassed descriptive statistics, with mean and standard deviation values, as well as distribution of absolute and relative frequency. To perform comparisons between proportions, the chi-square test was used, with level of significance $p<0.05$. The statistical program adopted was SPSS version 20.

\section{Results}

All the visually impaired individuals enrolled in APADEVI were invited to participate in the research, totaling 80 students. In the study, 40 subjects were assessed: 23 men (57.5\%) and 17 women (42.5\%), with mean age of $39.52( \pm 17.58)$ years for the men and $39.88( \pm$ 14.96) years for the women. The other students of the association did not attend the classes regularly or did not accept to participate in the study.

Of the 40 participants, all had visual impairment with different degrees of visual acuity: some were blind (their perception of light is insufficient to acquire knowledge through visual means) and some had low vision (they have difficulty in performing visual tasks, even with corrective lenses $)^{15}$. Within these two classifications, there are two forms of acquisition of the impairment: it can be congenital (the person has had the impairment since birth, due to heredity, albinism, intrauterine inflammations, etc.) or it can be acquired as a result of some other pathology, like astigmatism, cataract, diabetes, ocular trauma, among others.

Table 1 presents the distribution of frequency of the participants' type of impairment and the classification as inactive and active individuals. It is possible to see that a high percentage of physically inactive individuals was found among participants classified as blind and also among participants with low vision. When we analyze the participants as a whole, the result shows high prevalence of inactive individuals (70\%). However, in the comparison between the groups of congenital blindness, acquired blindness, congenital low vision and acquired low vision, no statistical difference was found $(p<0,05)$.

Table 1 - Distribution of frequencies in relation to type of impairment and level of physical activity, Guarapuava, Paraná $(n=40)$

\begin{tabular}{lccc}
\hline \multirow{2}{*}{ Variables } & Inactive & Active & \multirow{2}{*}{$\mathrm{p}$} \\
\cline { 2 - 3 } & $\mathrm{n}(\%)$ & $\mathrm{n}(\%)$ & \\
\hline Congenital blindness & $4(80.0)$ & $1(20.0)$ & \\
Acquired blindness & $7(70.0)$ & $3(30.0)$ & \multirow{2}{*}{0.552} \\
Congenital low vision & $4(50.0)$ & $4(50.0)$ & \\
Acquired low vision & $13(76.5 \%)$ & $4(23.5 \%)$ & \\
\hline
\end{tabular}

Chi-square test. Level of significance $\mathrm{p}<0.05$.

The results obtained by the questionnaire of barriers perception are presented in Tables 2 and 3. We decided to divide the results in two: Table 2 classifies the participants according to level of physical activity in active and inactive, and Table 3 classifies them according to visual impairment: congenital blindness, acquired blindness, congenital low vision and acquired low vision.

It is possible to see, in Table 2, that the factors that most interfere in the practice of physical activity, according to level of physical activity, are: "lack of support from family and/or friends", "bad mood" and "physical limitations". All these barriers were mentioned with higher prevalence by the participants classified as inactive, with responses "almost always/always" $(\mathrm{p}<0.05)$. In Table 3, no significant differences are observed for the barriers to physical activity between the groups of congenital blindness, acquired blindness, congenital low vision and acquired low vision $(\mathrm{p}>0.05)$.

The study also aimed to assess at which stages of behavior change in relation to physical activity the participants were (Table 4). In the comparison between congenital blindness, acquired blindness, congenital low vision and acquired low vision, no significant difference was found $(p<0,05)$.

\section{Discussion}

This study assessed the level of physical activity, the 
Table 2 - Distribution of frequencies of the visually impaired individuals in relation to barriers to physical activity practice, classified by level of physical activity, Guarapuava, Paraná $(n=40)$.

\begin{tabular}{|c|c|c|c|c|}
\hline \multirow[t]{2}{*}{ Variables } & $\begin{array}{c}\text { Never/ } \\
\text { Almost } \\
\text { never }\end{array}$ & Sometimes & $\begin{array}{l}\text { Almost } \\
\text { always/ } \\
\text { Always }\end{array}$ & \multirow[t]{2}{*}{$\mathrm{p}$} \\
\hline & $\mathrm{n}(\%)$ & $\mathrm{n}(\%)$ & $\mathrm{n}(\%)$ & \\
\hline \multicolumn{5}{|c|}{ Extensive working hours } \\
\hline Inactive & $27(96.4)$ & $1(3.6)$ & $0(0.0)$ & \multirow{2}{*}{0.249} \\
\hline Active & $11(91.7)$ & $0(0.0)$ & $0(0.0)$ & \\
\hline \multicolumn{5}{|c|}{ Family commitments } \\
\hline Inactive & $15(43.7)$ & $4(14.3)$ & $9(32.1)$ & \multirow{2}{*}{0.258} \\
\hline Active & $8(66.7)$ & $3(25.0)$ & $1(8.3)$ & \\
\hline \multicolumn{5}{|c|}{ Inadequate weather } \\
\hline Inactive & $8(28.6)$ & $2(7.1)$ & $18(64.3)$ & \multirow{2}{*}{0.057} \\
\hline Active & $6(50.0)$ & $3(25.0)$ & $3(25.0)$ & \\
\hline \multicolumn{5}{|c|}{ Lack of available space } \\
\hline Inactive & $6(21.4)$ & $1(3.6)$ & $21(75.0)$ & \multirow{2}{*}{0.351} \\
\hline Active & $2(16.7)$ & $2(16.7)$ & $8(66.7)$ & \\
\hline \multicolumn{5}{|c|}{ Lack of equipment } \\
\hline Inactive & $6(21.4)$ & $1(3.6)$ & $21(75.0)$ & \multirow{2}{*}{0.351} \\
\hline Active & $2(16.7)$ & $2(16.7)$ & $8(66.7)$ & \\
\hline \multicolumn{5}{|c|}{ Domestic chores } \\
\hline Inactive & $14(50.0)$ & $7(25.0)$ & $7(25.0)$ & \multirow{2}{*}{0.451} \\
\hline Active & $8(66.7)$ & $1(8.3)$ & $3(25.0)$ & \\
\hline \multicolumn{5}{|c|}{ Lack of company } \\
\hline Inactive & $8(28.6)$ & $3(10.7)$ & $17(60.7)$ & \multirow{2}{*}{0.420} \\
\hline Active & $5(41.7)$ & $0(0.0)$ & $7(58.3)$ & \\
\hline \multicolumn{5}{|c|}{$\begin{array}{l}\text { Lack of support from } \\
\text { family and/or friends }\end{array}$} \\
\hline Inactive & $13(46.4)$ & $2(7.1)$ & $13(46.4)$ & \multirow{2}{*}{0.011} \\
\hline Active & $9(75.0)$ & $3(25.0)$ & $0(0.0)$ & \\
\hline \multicolumn{5}{|c|}{ Lack of financial resources } \\
\hline Inactive & $12(42.9)$ & $4(14.3)$ & $12(42.9)$ & \multirow{2}{*}{0.157} \\
\hline Active & $4(33.3)$ & $5(41.7)$ & $3(25.0)$ & \\
\hline \multicolumn{5}{|l|}{ Bad mood } \\
\hline Inactive & $18(64.3)$ & $0(0.0)$ & $10(35.7)$ & \multirow{2}{*}{0.018} \\
\hline Active & $7(58.3)$ & $3(25.0)$ & $2(16.7)$ & \\
\hline \multicolumn{5}{|c|}{ Fear of being injured } \\
\hline Inactive & $7(25.0)$ & $2(7.1)$ & $19(67.9)$ & 0,543 \\
\hline Active & $5(41.7)$ & $1(8.3)$ & $6(50.0)$ & 0.343 \\
\hline Physical li. & & & & \\
\hline Inactive & $5(17.9)$ & $0(0.0)$ & $23(82.1)$ & 0034 \\
\hline Active & $4(33.3)$ & $2(16.7)$ & $6(50.0)$ & 0.034 \\
\hline Lack of en & & & & \\
\hline Inactive & $13(46.4)$ & $2(7.1)$ & $13(46.4)$ & 441 \\
\hline Active & $66.7 \%$ & $1(8.3)$ & $3(25.0)$ & 0.441 \\
\hline Mild pain & & & & \\
\hline Inactive & $13(46.4)$ & $4(14.3)$ & $11(39.3)$ & 0.684 \\
\hline Active & $7(58.3)$ & $2(16.7)$ & $3(25.0)$ & 0.684 \\
\hline Lack of ph & & & & \\
\hline Inactive & $6(21.4)$ & $2(7.1)$ & $20(71.4)$ & 06 \\
\hline Active & $7(58.3)$ & $0(0.0)$ & $5(41.7)$ & 0.062 \\
\hline
\end{tabular}

Continue...
... continue

\begin{tabular}{|c|c|c|c|c|}
\hline \multirow[t]{2}{*}{ Variables } & $\begin{array}{c}\text { Never/ } \\
\text { Almost } \\
\text { never }\end{array}$ & Sometimes & $\begin{array}{l}\text { Almost } \\
\text { always/ } \\
\text { Always }\end{array}$ & \multirow[t]{2}{*}{$\mathrm{p}$} \\
\hline & $\mathrm{n}(\%)$ & n (\%) & $\mathrm{n}(\%)$ & \\
\hline \multicolumn{5}{|c|}{$\begin{array}{l}\text { Lack of knowledge or } \\
\text { guidance about physical } \\
\text { activity }\end{array}$} \\
\hline Inactive & $8(28.6)$ & $2(7.1)$ & $18(64.3)$ & \multirow{2}{*}{0.100} \\
\hline Active & $2(16.7)$ & $4(33.3)$ & $6(50.0)$ & \\
\hline \multicolumn{5}{|c|}{$\begin{array}{l}\text { Insufficiently safe } \\
\text { environment }\end{array}$} \\
\hline Inactive & $7(25.0)$ & $1(3.6)$ & $20(71.4)$ & \multirow{2}{*}{0.492} \\
\hline Active & $5(41.7)$ & $0(0.0)$ & $7(58.3)$ & \\
\hline \multicolumn{5}{|c|}{$\begin{array}{l}\text { Concern about one's } \\
\text { appearance during practice }\end{array}$} \\
\hline Inactive & $18(64.3)$ & $1(3.6)$ & $9(32.1)$ & \multirow{2}{*}{0.806} \\
\hline Active & $7(58.3)$ & $1(8.3)$ & $4(33.3)$ & \\
\hline \multicolumn{5}{|c|}{$\begin{array}{l}\text { Lack of interest in } \\
\text { practicing }\end{array}$} \\
\hline Inactive & $21(75.0)$ & $3(10.7)$ & $4(14.3)$ & \multirow{2}{*}{0.162} \\
\hline Active & $12(100.0)$ & $0(0.0)$ & $0(0.0)$ & \\
\hline
\end{tabular}

Chi-square test. Level of significance $\mathrm{p}<0.05$

Table 3 - Distribution of frequency of the visually impaired individuals in relation to barriers to physical activity practice, classified by level of impairment, Guarapuava, Paraná $(n=40)$.

\begin{tabular}{|c|c|c|c|c|}
\hline \multirow[t]{2}{*}{ Variables } & $\begin{array}{c}\text { Never/ } \\
\text { Almost } \\
\text { never }\end{array}$ & Sometimes & $\begin{array}{l}\text { Almost } \\
\text { always/ } \\
\text { Always }\end{array}$ & \multirow[t]{2}{*}{$\mathrm{p}$} \\
\hline & $\mathrm{n}(\%)$ & $\mathrm{n}(\%)$ & $\mathrm{n}(\%)$ & \\
\hline \multicolumn{5}{|l|}{ Extensive working hours } \\
\hline Congenital blindness & $5(100.0)$ & $0(0.0)$ & $0(0.0)$ & \multirow{4}{*}{0.309} \\
\hline Acquired blindness & $9(90.0)$ & $1(10.0)$ & $0(0.0)$ & \\
\hline Congenital low vision & $7(87.5)$ & $0(0.0)$ & $1(12.5)$ & \\
\hline Acquired low vision & $17(10.0)$ & $0(0.0)$ & $0(0.0)$ & \\
\hline \multicolumn{5}{|l|}{ Family commitments } \\
\hline Congenital blindness & $3(60.0)$ & $2(40.0)$ & $0(0.0)$ & \multirow{4}{*}{0.095} \\
\hline Acquired blindness & $5(50.0)$ & $3(30.0)$ & $2(20.0)$ & \\
\hline Congenital low vision & $5(62.5)$ & $3(37.5)$ & $0(0.0)$ & \\
\hline Acquired low vision & $8(47.1)$ & $1(5.9)$ & $8(47.1)$ & \\
\hline \multicolumn{5}{|l|}{ Inadequate weather } \\
\hline Congenital blindness & $1(20.0)$ & $1(20.0)$ & $3(60.0)$ & \multirow{4}{*}{0.651} \\
\hline Acquired blindness & $4(40.0)$ & $1(10.0)$ & $5(50.0)$ & \\
\hline Congenital low vision & $4(50.0)$ & $2(25.0)$ & $2(25.0)$ & \\
\hline Acquired low vision & $4(23.5)$ & $2(11.8)$ & $11(64.7)$ & \\
\hline \multicolumn{5}{|l|}{ Lack of available space } \\
\hline Congenital blindness & $2(40.0)$ & $0(0.0)$ & $3(60.0)$ & \multirow{4}{*}{0.394} \\
\hline Acquired blindness & $2(20.0)$ & $1(10.0)$ & $7(70.0)$ & \\
\hline Congenital low vision & $0(0.0)$ & $0(0.0)$ & $8(100.0)$ & \\
\hline Acquired low vision & $3(17.6)$ & $3(17.6)$ & $11(64.7)$ & \\
\hline \multicolumn{5}{|l|}{ Lack of equipment } \\
\hline Congenital blindness & $2(40.0)$ & $0(0.0)$ & $3(60.0)$ & \multirow{4}{*}{0.394} \\
\hline Acquired blindness & $2(20.0)$ & $1(10.0)$ & $7(70.0)$ & \\
\hline Congenital low vision & $0(0.0)$ & $0(0.0)$ & $8(100.0)$ & \\
\hline Acquired low vision & $3(17.6)$ & $3(17.6)$ & $11(64.7)$ & \\
\hline
\end{tabular}

Continue... 
... continue

\begin{tabular}{|c|c|c|c|c|}
\hline \multirow[t]{2}{*}{ Variables } & $\begin{array}{l}\text { Never/ } \\
\text { Almost } \\
\text { never }\end{array}$ & Sometimes & $\begin{array}{l}\text { Almost } \\
\text { always/ } \\
\text { Always }\end{array}$ & \multirow[t]{2}{*}{$\mathrm{p}$} \\
\hline & $\mathrm{n}(\%)$ & $\mathrm{n}(\%)$ & $\mathrm{n}(\%)$ & \\
\hline \multicolumn{5}{|l|}{ Domestic chores } \\
\hline Congenital blindness & $2(40.0)$ & $2(40.0)$ & $1(20.0)$ & \multirow{4}{*}{0.842} \\
\hline Acquired blindness & $6(60.0)$ & $2(20.0)$ & $2(20.0)$ & \\
\hline Congenital low vision & $4(50.0)$ & $1(12.5)$ & $3(37.5)$ & \\
\hline Acquired low vision & $7(41.2)$ & $6(35.3)$ & $4(23.5)$ & \\
\hline \multicolumn{5}{|l|}{ Lack of company } \\
\hline Congenital blindness & $0(0.0)$ & $2(40.0)$ & $3(60.0)$ & \multirow{4}{*}{0.137} \\
\hline Acquired blindness & $4(40.0)$ & $2(20.0)$ & $4(40.0)$ & \\
\hline Congenital low vision & $1(12.5)$ & $0(0.0)$ & $7(87.5)$ & \\
\hline Acquired low vision & $6(35.3)$ & $1(5.9)$ & $10(58.8)$ & \\
\hline \multicolumn{5}{|l|}{$\begin{array}{l}\text { Lack of support from } \\
\text { family and/or friends }\end{array}$} \\
\hline Congenital blindness & $2(40.0)$ & $1(20.0)$ & $2(40.0)$ & \multirow{4}{*}{0.989} \\
\hline Acquired blindness & $6(62.5)$ & $1(12.5)$ & $3(25.0)$ & \\
\hline Congenital low vision & $5(62.5)$ & $1(12.5)$ & $2(25.0)$ & \\
\hline Acquired low vision & $9(52.9)$ & $2(11.8)$ & $6(35.3)$ & \\
\hline \multicolumn{5}{|l|}{ Lack of financial resources } \\
\hline Congenital blindness & $2(40.0)$ & $2(40.0)$ & $1(20.0)$ & \multirow{4}{*}{0.866} \\
\hline Acquired blindness & $3(30.0)$ & $2(20.0)$ & $5(50.0)$ & \\
\hline Congenital low vision & $4(50.0)$ & $2(25.0)$ & $2(25.0)$ & \\
\hline Acquired low vision & $5(29.4)$ & $5(29.4)$ & $7(41.2)$ & \\
\hline \multicolumn{5}{|l|}{ Bad mood } \\
\hline Congenital blindness & $3(60.0)$ & $1(20.0)$ & $1(20.0)$ & \multirow{4}{*}{0.636} \\
\hline Acquired blindness & $6(60.0)$ & $2(20.0)$ & $2(20.0)$ & \\
\hline Congenital low vision & $6(75.0)$ & $0(0.0)$ & $2(25.0)$ & \\
\hline Acquired low vision & $9(52.9)$ & $1(5.9)$ & $7(41.2)$ & \\
\hline \multicolumn{5}{|l|}{ Fear of being injured } \\
\hline Congenital blindness & $0(0.0)$ & $0(0.0)$ & $5(100.0)$ & \multirow{4}{*}{0.425} \\
\hline Acquired blindness & $2(20.0)$ & $2(20.0)$ & $6(60.0)$ & \\
\hline Congenital low vision & $3(37.5)$ & $0(0.0)$ & $5(62.5)$ & \\
\hline Acquired low vision & $6(35.3)$ & $2(11.8)$ & $9(52.9)$ & \\
\hline \multicolumn{5}{|l|}{ Physical limitations } \\
\hline Congenital blindness & $0(0.0)$ & $1(20.0)$ & $4(80.0)$ & \multirow{4}{*}{0.711} \\
\hline Acquired blindness & $3(30.0)$ & $1(10.0)$ & $6(60.0)$ & \\
\hline Congenital low vision & $1(12.5)$ & $0(0.0)$ & $7(87.5)$ & \\
\hline Acquired low vision & $3(17.6)$ & $2(11.8)$ & $12(70.6)$ & \\
\hline \multicolumn{5}{|l|}{ Lack of energy } \\
\hline Congenital blindness & $1(20.0)$ & $0(0.0)$ & $4(80.0)$ & \multirow{4}{*}{0.134} \\
\hline Acquired blindness & $5(50.0)$ & $3(30.0)$ & $2(20.0)$ & \\
\hline Congenital low vision & $5(62.5)$ & $0(0.0)$ & $3(37.5)$ & \\
\hline Acquired low vision & $9(52.9)$ & $1(5.9)$ & $7(41.2)$ & \\
\hline \multicolumn{5}{|l|}{ Mild pain and discomfort } \\
\hline Congenital blindness & $2(40.0)$ & $1(20.0)$ & $2(40.0)$ & \multirow{4}{*}{0.994} \\
\hline Acquired blindness & $4(40.0)$ & $3(30.0)$ & $3(30.0)$ & \\
\hline Congenital low vision & $3(37.5)$ & $2(25.0)$ & $3(37.5)$ & \\
\hline Acquired low vision & $8(47.1)$ & $3(22.5)$ & $6(35.0)$ & \\
\hline
\end{tabular}

Continue...

\begin{tabular}{|c|c|c|c|c|}
\hline \multirow[t]{2}{*}{ Variables } & $\begin{array}{l}\text { Never/ } \\
\text { Almost } \\
\text { never }\end{array}$ & Sometimes & $\begin{array}{l}\text { Almost } \\
\text { always/ } \\
\text { Always }\end{array}$ & \multirow[t]{2}{*}{$\mathrm{p}$} \\
\hline & $\mathrm{n}(\%)$ & $\mathrm{n}(\%)$ & $\mathrm{n}(\%)$ & \\
\hline \multicolumn{5}{|l|}{ Lack of physical ability } \\
\hline Congenital blindness & $1(20.0)$ & $1(20.0)$ & $3(60.0)$ & \multirow{4}{*}{0.801} \\
\hline Acquired blindness & $4(40.0)$ & $1(10.0)$ & $5(50.0)$ & \\
\hline Congenital low vision & $2(25.0)$ & $1(12.5)$ & $5(62.5)$ & \\
\hline Acquired low vision & $2(11.8)$ & $3(17.6)$ & $12(70.6)$ & \\
\hline \multicolumn{5}{|l|}{$\begin{array}{l}\text { Lack of knowledge or } \\
\text { guidance about physical } \\
\text { activity }\end{array}$} \\
\hline Congenital blindness & $1(20.0)$ & $1(20.0)$ & $3(60.0)$ & \multirow{4}{*}{0.320} \\
\hline Acquired blindness & $4(40.0)$ & $0(0.0)$ & $6(60.0)$ & \\
\hline Congenital low vision & $0(0.0)$ & $1(12.5)$ & $7(87.5)$ & \\
\hline Acquired low vision & $5(29.4)$ & $4(23.5)$ & $8(47.1)$ & \\
\hline \multicolumn{5}{|l|}{$\begin{array}{l}\text { Insufficiently safe } \\
\text { environment }\end{array}$} \\
\hline Congenital blindness & $0(0.0)$ & $0(0.0)$ & $5(100.0)$ & \multirow{4}{*}{0.511} \\
\hline Acquired blindness & $1(10.0)$ & $1(10.0)$ & $8(80.0)$ & \\
\hline Congenital low vision & $2(25.0)$ & $1(12.5)$ & $5(62.5)$ & \\
\hline Acquired low vision & $6(35.3)$ & $2(11.8)$ & $9(52.9)$ & \\
\hline \multicolumn{5}{|l|}{$\begin{array}{l}\text { Concern about one's } \\
\text { appearance during } \\
\text { practice }\end{array}$} \\
\hline Congenital blindness & $4(80.0)$ & $0(0.0)$ & $1(20.0)$ & \multirow{4}{*}{0.816} \\
\hline Acquired blindness & $7(70.0)$ & $0(0.0)$ & $3(30.0)$ & \\
\hline Congenital low vision & $4(50.0)$ & $1(12.5)$ & $3(37.5)$ & \\
\hline Acquired low vision & $9(52.9)$ & $2(11.8)$ & $6(35.3)$ & \\
\hline \multicolumn{5}{|l|}{$\begin{array}{l}\text { Lack of interest in } \\
\text { practicing }\end{array}$} \\
\hline Congenital blindness & $4(80.0)$ & $1(20.0)$ & $0(0.0)$ & \multirow{4}{*}{0.377} \\
\hline Acquired blindness & $6(60.0)$ & $1(10.0)$ & $3(30.0)$ & \\
\hline Congenital low vision & $7(87.5)$ & $1(12.5)$ & $0(0.0)$ & \\
\hline Acquired low vision & $14(82.4)$ & $2(11.8)$ & $1(5.9)$ & \\
\hline
\end{tabular}

Chi-square test. Level of significance $\mathrm{p}<0.05$.

perception of barriers to practice and the stages of behavior change of visually impaired individuals. The main results were: a) high prevalence of inactive subjects $(70 \%)$; b) the main barriers mentioned by the inactive subjects were: "lack of support from family and/or friends", "bad mood" and "physical limitations".

In an assessment of level of physical activity with 575 non-impaired individuals of both sexes aged between 20 and 39 years, the researchers found a prevalence of physical inactivity of $57.4 \%{ }^{15}$. Thus, the comparison between visually impaired and non-impaired individuals shows similarity of behavior among the subjects, who present more than $50 \%$ of prevalence of physical inactivity.

Among the barriers, the most relevant factor that emerges as the main limiting factor is "lack of support 
Table 4-Distribution of frequency of the visually impaired individuals in relation to the stages of behavior change, Guarapuava, Paraná $(\mathrm{n}=40)$

\begin{tabular}{lcccccc}
\hline \multirow{2}{*}{ Variables } & Pre-contemplation & Contemplation & Preparation & Maintenance & Action & $\mathrm{p}$ \\
\cline { 2 - 5 } & $\mathrm{n}(\%)$ & $\mathrm{n}(\%)$ & $\mathrm{n}(\%)$ & $\mathrm{n}(\%)$ & $\mathrm{n}(\%)$ & $0(0.0)$ \\
\hline Congenital blindness & $0(0.0)$ & $2(40.0)$ & $3(60.0)$ & $0(0.0)$ & $3(30.0)$ & $0(0.0)$ \\
Acquired blindness & $0(0.0)$ & $4(40.0)$ & $3(30.0)$ & $6(75 \%)$ & $1(12.5)$ & $0(0.0)$ \\
Congenital low vision & $0(0.0)$ & $1(12.5)$ & $8(47.1)$ & $1(5.59)$ & $1(5.59)$ \\
Acquired low vision & $1(5.9)$ & $6(35.3)$ & & \\
\hline
\end{tabular}

Chi-square test Level of significance $\mathrm{p}<0.05$

from family and/or friends" (43.4\%), caused by overprotection or by the belief that these individuals do not have skills to be physically active. This result was also found by Morgado et $\mathrm{al}^{7}$, who assessed, in a qualitative way, facilitating and limiting factors for physical activity practice in 11 subjects with congenital blindness. The researchers found that the family is a limiting factor, but also a facilitating one, which involves issues like motivation and support. Concerning this factor, the professionals must intervene not only in the individual, but also in the family and in the people who are close to the individual. The role of family and friends can be understood as an important source of support and incentive, so that the visually impaired can view physical activity as a way of improving their quality of life and even their social development ${ }^{6}$. However, in some cases, the family can be an obstacle to the practice of physical activity, due to overprotection or to the belief that visually impaired individuals do not have motor ability and can be injured in some way, which makes them remain dependent on their family. Due to this, it is of paramount importance that the family be educated about different adaptation strategies of physical activities for the visually impaired, in order to provide them with opportunities to adopt a healthy lifestyle and to become autonomous ${ }^{16}$.

The second most prevalent barrier was "physical limitations". Due to the visual limitation, the participants report having difficulties in learning and performing the activities of daily living, as well as difficulties in locomotion, spatial and temporal organization, among others. We can consider, as justifications, the visual limitation and the little amount of time destined for the practice of physical activity in the association's environment. This barrier can be solved through the teaching of these skills in the physical education classes attended by the participants. This teaching can include activities that favor the acquisition of basic skills like walking, running, jumping, exploration of objects and devices, real environments and situations, in an attempt to help them fully use their sensory potential, among other strategies.
The barrier of "bad mood" also emerges as a factor that limits physical activity, more prevalent among the inactive individuals, compared to the active ones. In a study with obese subjects, it was found that this barrier is related to a decrease in the motivation to physical activity practice, which can be improved through modifications in subjects' body composition ${ }^{17}$.

Other barriers like the "weather factor" emerge as possible aggravating factors, but did not have statistical difference. Rain, cold weather or very hot weather can also justify the non-practice of physical activities. Rain, for example, limits the practice of activities (88.5\%). The study was carried out in Guarapuava, an inland city of the State of Paraná located in the third plateau, with an altitude of 1,200 meters, which makes it be one of the coldest cities of the State. In a study with non-impaired elderly individuals of both sexes, the researchers reported that $39.7 \%$ of the participants mentioned this same barrier ${ }^{18}$. Moreover, the elderly perceived that the weather prevents the person from having a good physical performance. It is necessary to raise subjects' awareness in relation to the weather: it is merely an environmental aspect, not a factor that limits the practice of physical activity. In cold and rainy days, searching for closed places can be a strategy to mitigate this factor. In hot weather, the strategy can be the opposite of the previous one: searching for open spaces like parks and squares and practicing lighter activities.

We conclude that the visually impaired individuals of both sexes, active and inactive, perceive, as barriers to physical activity, lack of support from family and/or friends, physical limitations and bad mood. The study presented some strategies to solve these barriers, but further research is needed on the theme. The identification of barriers is an important aid to the development of intervention, adherence and health promotion programs.

\section{Conflicts of interest}

The authors declare there are no conflicts of interest. 


\section{Authors' contribution}

Matoso GP participated in the initial conception of the study, data collection, and in the writing and critical review of the text. Portela BS participated in the initial conception of the study, statistical analysis, and in the writing and critical review of the text.

\section{References}

1. Penedo FJ, Dahn JR. Exercise and well-being: a review of mental and physical health benefits associated with physical activity. Curr Opin Psychiatry. 2005;18(2):189-93.

2. Janssen I, Leblanc AG. Systematic review of the health benefits of physical activity and fitness in school-aged children and youth. Inter. J Behav Nutr Phys Act. 2010;7(40):1-16.

3. Malta DC, Stopa SR, Canuto R, Gomes NL, Mendes VLF, Goulart BNGD et al. Prevalência autorreferida de deficiência no Brasil, segundo a Pesquisa Nacional de Saúde, 2013. Ciênc. Saúde Colet. 2016;21(10):3253-64.

4. Kozub FM, Oh H. An exploratory study of physical activity levels in children and adolescents with visual impairments. Clinical Kinesiology. 2004;58(3):1-7.

5. Stuart ME, Lieberman L, Hand KE. Beliefs about physical activity among children who are visually impaired and their parents. J Vis Impair Blind. 2006;100(4):223-34.

6. Lieberman LJ. Fitness for individuals who are visually impaired or deaf blind. Rehabilitation and Education for Blindness and Visual Impairment. 2002;34(1), 13-23.

7. Morgado FFDR, Campana ANNB, Morgado JJM, Fortes LDS, Tavares MDCGCF. Facilitadores e barreiras percebidos por pessoas com cegueira congênita para a prática de atividade física. Rev. bras. educ. espec. 2013;19(3):379-94.

8. Brazão MC, Hirayama MS, Gobbi S, Nascimento CMC; Roseguini AZ. Estágios de mudança de comportamento e barreiras percebidas à prática de atividade física em idosos residentes em uma cidade de médio porte do Brasil. Motriz. 2009;15(4):759-67.

9. Petroski EL, Silva DAS, Reis RS, Pelegrini A. Estágios de mudança de comportamento e percepção positiva do ambiente para atividade física em usuários de parque urbano. Motricidade. 2009;5(2):17-31.
10. Craig CL, Marshall AL, Sjostrom M, Bauman AE, Booth ML, Ainsworth BE. International physical activity questionnaire: 12-country reliability and validity. Med Sci Sports Exerc. 2003;35(8):1381-95.

11. Matsudo S, Araújo T, Andrade D, Matsudo V, Andrade E, Oliveira LC, et al. Questionário internacional de atividade física (IPAQ): estudo de validade e reprodutibilidade no Brasil. Rev Bras Ativ Fís Saúde. 2001;6(2):05-18.

12. Tremblay MS, Aubert S, Barnes JD, Saunders TJ, Carson V, Latimer-Cheung AE, et al. Sedentary behavior research network (SBRN)-terminology consensus project process and outcome. Int J Behav Nutr Phys Act. 2017;14(1):5-81.

13. Martins MO, Petroski EL. Mensuração da percepção de barreiras para a prática de atividades físicas: uma proposta de instrumento. Rev Bras Cineantropom Desempenho Hum. 2000;2(1):58-65.

14. Rigoni PAG, Nascimento JRAD, Costa GNFDS, Vieira LF. Estágios de mudança de comportamento e percepção de barreiras para a prática de atividade física em universitários do curso de Educação Física. Rev Bras Ativ Fís Saúde. 2012;17(2):87-92.

15. Barreta E, Barreta M, Peres KG. Nível de atividade física e fatores associados em adultos no Município de Joaçaba, Santa Catarina, Brasil. Cad. Saúde Pública. 2007;23(7):1595-1602.

16. Greguol M, Gobbi E, Carraro A. Physical activity practice among children and adolescents with visual impairment influence of parental support and perceived barriers. Disabil Rehabil. 2015;37(4):327-30.

17. Boscatto EC, Duarte MDFDS, Gomes MDA. Estágios de mudança de comportamento e barreiras para a atividade física em obesos mórbidos. Rev Bras Cineantropom Desempenho Hum. 2011;13(5), 329-34.

18. Nascimento CMC, Gobbi S, Hirayama MS, Brazão MC. Nível de atividade física e as principais barreiras percebidas por idosos de rio claro. Rev. Educ. Fís/UEM. 2008;19(1):109-18.

Received: $12 / 20 / 2018$ Approved: 11/29/2019 